Contributions:

A Study design/planning

B Data collection/entry

C Data analysis/statistics

D Data interpretation

E Preparation of manuscript

F Literature analysis/search

$\mathrm{G}$ Funds collection

\title{
SURGICAL TREATMENT OF A 5-YEAR-OLD BOY WITH OTOSCLEROSIS: A CASE STUDY
}

\author{
Henryk Skarzynski ${ }^{1 A B C E F}$, Monika Boruta ${ }^{1 A B C E F}$, Beata Dziendziel ${ }^{2 C E F}$, \\ Joanna J. Rajchel ${ }^{2 \mathrm{EF}}$, Piotr H. Skarzynski ${ }^{2,3,4 \mathrm{AE}}$
}

${ }^{1}$ Oto-Rhino-Laryngology Surgery Clinic, Institute of Physiology and Pathology of Hearing, Warsaw/Kajetany, Poland

${ }^{2}$ Department of Teleaudiology, World Hearing Center, Institute of Physiology and Pathology of Hearing, Warsaw/Kajetany, Poland

${ }^{3}$ Institute of Sensory Organs, Kajetany, Poland

${ }^{4}$ Department of Heart Failure and Cardiac Rehabilitation, Medical University of Warsaw, Warsaw, Poland

Corresponding author: Piotr H. Skarzynski, Address: Mokra 17, 05-830 Kajetany, Poland, Tel. +48 2235603 83, E-mail: p.skarzynski@ifps.org.pl

\begin{abstract}
Otosclerosis is most often diagnosed in adults, especially women. It is much less common in children and even rarer in boys. The aim of this paper is to present the case history and results of surgical treatment of a 5-year-old boy with bilateral conductive hearing loss and tinnitus. Results of surgical treatment show mean air-bone closure of $25 \mathrm{~dB}$ and cessation of tinnitus. Surgical treatment for otosclerosis is recommended regardless of the patient's age. Additional motivations for surgical intervention in children are: severe progressive hearing loss, tinnitus, and rising bone-conduction threshold.
\end{abstract}

Key words: juvenile otosclerosis; children; stapedotomy

\section{TRATAMIENTO QUIRÚRGICO DE LA OTOESCLEROSIS EN UN NIÑO DE 5 AÑOS - ESTUDIO DE CASO}

\begin{abstract}
Resumen
La otoesclerosis se diagnostica con más frecuencia en adultos, sobre todo en las mujeres. Es mucho menos común en niños, entre ellos menos aún en niños varones. El objetivo del presente trabajo fue presentar la historia clínica y los resultados del tratamiento quirúrgico de un niño varón de 5 años de edad con hipoacusia conductiva bilateral y tinnitus. El resultado del tratamiento quirúrgico indica la disminución del tamaño de la reserva coclear en $25 \mathrm{~dB}$ HL por término medio y la desaparición del tinnitus. El tratamiento quirúrgico de la otoesclerosis está indicado independientemente de la edad del paciente. Una justificación adicional para realizar la cirugía en niños es el diagnóstico de hipoacusia significativa y progresiva, tinnitus y aumento del umbral de conducción ósea.
\end{abstract}

Palabras clave: otoesclerosis infantil; niños; estapedotomía

ХИРУРГИЧЕСКОЕ ЛЕЧЕНИЕ ОТОСКЛЕРОЗА У ПЯТИЛЕТНЕГО МАЛЬЧИКА АНАЛИЗ СЛУЧАЯ

\section{Абстракт}

Отосклероз чаще всего диагностируется у взрослых людей, особенно у женщин. Намного реже он встречается у детей, а среди них ещё реже у мальчиков. Целью работы было представить историю болезни, а также результаты операционного лечения пятилетнего мальчика с двусторонней кондуктивной тугоухостью и шумом в ушах. Результат операционного лечения поазывает уменьшение размера резерва улитки в среднем на 25 дБ HL, а также исчезновение шума в ушах. Операционное лечение отосклероза рекомендуется вне зависимости от возраста пациента. Дополнительным показанием для проведения операции у детей является обнаружение значительной, прогрессирующей тугоухости, наличие шума в ушах и повышение порога костной проводимости.

Ключевые слова: детский отосклероз; дети; стапедотомия 


\title{
CHIRURGICZNE LECZENIE OTOSKLEROZY U 5-LETNIEGO CHŁOPCA - STADIUM PRZYPADKU
}

\begin{abstract}
Abstrakt
Otoskleroza jest rozpoznawana najczęściej u osób dorosłych, zwłaszcza kobiet. Znacznie rzadziej spotykamy ją u dzieci, a wśród nich jeszcze rzadziej u chłopców. Celem pracy było przedstawienie historii choroby oraz wyników operacyjnego leczenia 5 letniego chłopca z obustronnym przewodzeniowym niedosłuchem oraz szumami usznymi. Wynik leczenia operacyjnego wskazuje na zmniejszenie wielkości rezerwy ślimakowej średnio o 25dB HL oraz ustąpienie szumu usznego. Leczenie operacyjne otosklerozy jest wskazane bez względu na wiek pacjenta. Dodatkowym uzasadnieniem dla wykonania operacji u dzieci jest stwierdzenie znacznego, postępującego niedosłuchu, występowanie szumów usznych oraz podwyższanie się progu przewodnictwa kostnego.
\end{abstract}

Słowa kluczowe: otoskleroza dziecięca; dzieci; stapedotomia

\section{Introduction}

Otosclerosis in children (called also juvenile otosclerosis) is diagnosed infrequently, and even more rarely in boys. Due to the rarity and lack of documentation for a progressive disease in a child, an incorrect diagnosis of congenital stapes ankylosis or other congenital middle ear defect can be made (1). Guild (2) in his study of temporal bones describes one case of histologic otosclerosis in 161 temporal bones of children below 5 years of age, a figure which amounts to about $0.6 \%$ of the population. In the population between 5 and 18 years of age the incidence rises to $4 \%(2)$.

Computed tomography (CT) imaging is considered the 'gold standard' in the assessment of the oval window, cochlea, internal auditory canal, vestibule, ossicles, and facial nerve $(3,4)$. CT is also useful in preoperative diagnosis of otosclerosis in adults, allowing otosclerosis to be predicted in $85 \%$ of cases (5). There are no publications directly proving the usefulness of CT in diagnosing otosclerosis on a large pediatric material, although published series of

RIGHTEAR

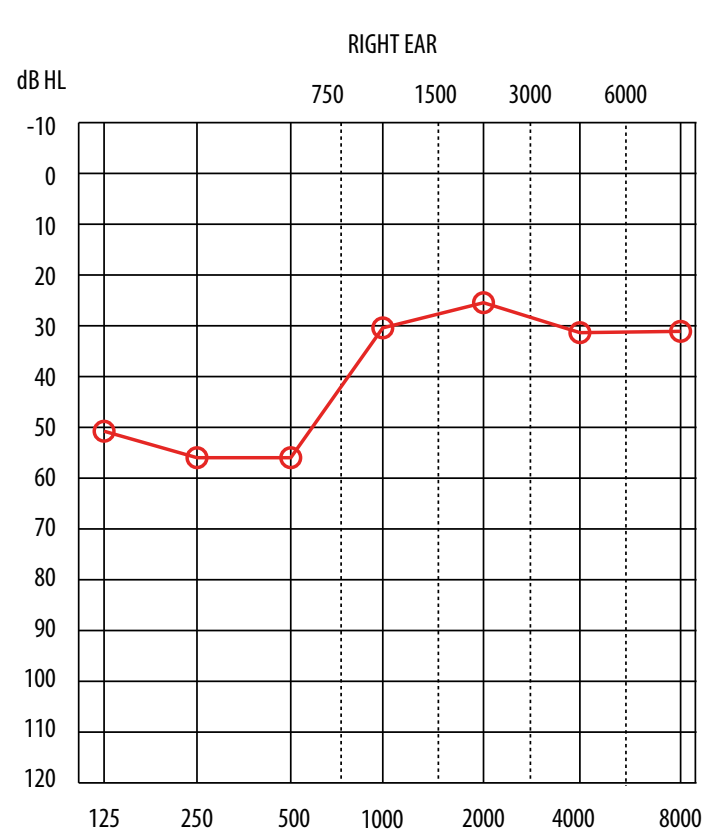

cases demonstrate that it is helpful in preoperative assessment (6). Nevertheless CT is considered an obligatory examination (7), because it makes it possible to predict the potential effects of surgical intervention. CT also makes it possible to limit unnecessary risks such as perilymphatic gusher, which might lead to sensorineural hearing loss as a complication (8).

An effective treatment is stapedotomy, surgery which consists in removal of the stapes superstructure, making a hole in the immobilized and often thickened stapes footplate, and inserting into the vestibule an appropriate prosthesis fixed to the long process of the incus. While this method of treatment is routine in adults, its application in children is uncommon. This is confirmed by the small number of published reports of treatment in children, especially small children, compared to the number of papers reporting the results of treatment in adults (9). A review of the literature on surgical treatment of otosclerosis in children makes it possible to identify leaders with extensive experience in surgical treatment for pediatric otosclerosis:

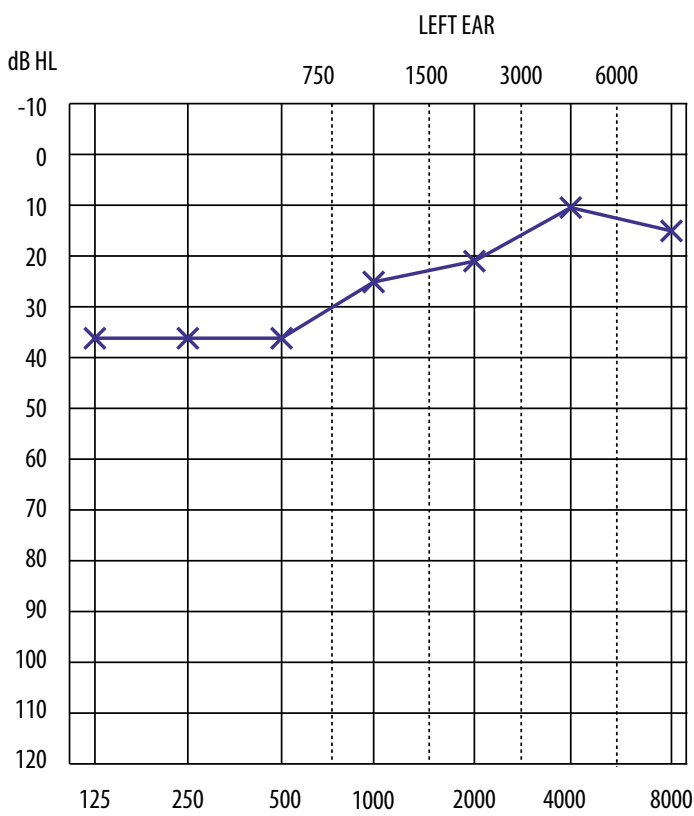

Figure 1. Results of pure-tone audiometry performed when the patient was four years old, showing approximate air conduction thresholds in the right and left ear 
a. Millman and al. (1996), who report on 40 stapedotomies, the youngest child in their group was 7 years old (10);

b. Lippy et al. (1998) report 60 ear surgeries in 47 children, the youngest 7 years (11);

c. de la Cruz et al. (1999) report on a group of 81 children and adolescents younger than 18 years, in which 95 ears were operated for otosclerosis and congenital stapes fixation (12);

d. Denoyelle et al. (2010) performed 35 stapedotomies in children, including 25 for congenital stapes fixation, 6 for otosclerosis, 3 for posttraumatic ossicular damage, and 1 for osteogenesis imperfecta (13);

e. Carlson et al. (2013) performed 44 stapedotomies in children for congenital stapes fixation or otosclerosis (14);

f. Vincent et al. (2016) report 41 stapedotomies for otosclerosis in children, of whom the youngest was 8 years old (15);

g. Skarzynski et al. (2018) have described the largest group in the literature: 278 stapedotomies in children and adolescents younger than 18 years, including 213 for otosclerosis, 44 for congenital fixation of the stapes or whole ossicular chain, and 21 for posttraumatic ossicular damage (16).

The aim of this paper is to retrospectively present the case history and results of surgical treatment of probably the youngest child described in the literature until now: a 5-year-old boy who underwent surgery due to bilateral conductive hearing loss and tinnitus.

\section{Case report}

The boy was qualified for surgery - exploratory tympanotomy - at the World Hearing Center in the first half of 2016 when younger than 5 years. He had bilateral progressive hearing loss and tinnitus. Tinnitus was chronic on the left side and intermittent on the right side. The medical interview revealed no previous otitis media with effusion. The family history regarding otosclerosis and congenital defects was negative. On interview it was ascertained that the child had obtained pass results in the otoacoustic emissions (OAE) test during newborn hearing screening, which is performed on all newborns in Poland $(17,18)$. Subsequently, after an extended infection of upper airways, he had an impedance audiometry test at the age of 1 year and 6 months, with pass results. Due to a suspicion of delayed speech development, an auditory brainstem response (ABR) test was performed, which did not reveal any abnormalities. When the boy was 2 years and 6 months old, after another infection involving the upper airways and both ears, the parents reported that they started to suspect a hearing impairment in their child. After infection receded, tympanometry was performed and it showed no acoustic reflexes bilaterally from the stapedius muscle and normal type A tympanograms. In the follow-up ABR using a chirp stimulus, thresholds of $20 \mathrm{~dB}$ $\mathrm{nHL}$ in the right ear and $30 \mathrm{~dB} \mathrm{nHL}$ in the left ear were obtained. When the boy was 3 years and 4 months old, he underwent another ABR, which showed increased hearing thresholds in both ears. In the right ear, hearing thresholds were $20 \mathrm{~dB}$ nHL for $500 \mathrm{~Hz}$ and $30 \mathrm{~dB}$ nHL for 2000 and $4000 \mathrm{~Hz}$; in the left ear hearing thresholds were $40 \mathrm{~dB}$ nHL for $500 \mathrm{~Hz}$ and $30 \mathrm{~dB}$ for 2000 and $4000 \mathrm{~Hz}$. Due to persistent problems with speech development, the boy was under the care of a speech and language therapist who observed that the child had increasing difficulties with hearing some sounds. When the boy was 3 years and 9 months old, an ABR test with a chirp-type stimulus recorded bilateral hearing impairment at a level of $30 \mathrm{~dB} n \mathrm{~nL}$ in the right ear and $40 \mathrm{~dB} \mathrm{nHL}$ in the left. For this reason, he was referred for hearing aid fitting in the worse hearing ear, but he did not tolerate hearing aids. When he was 4
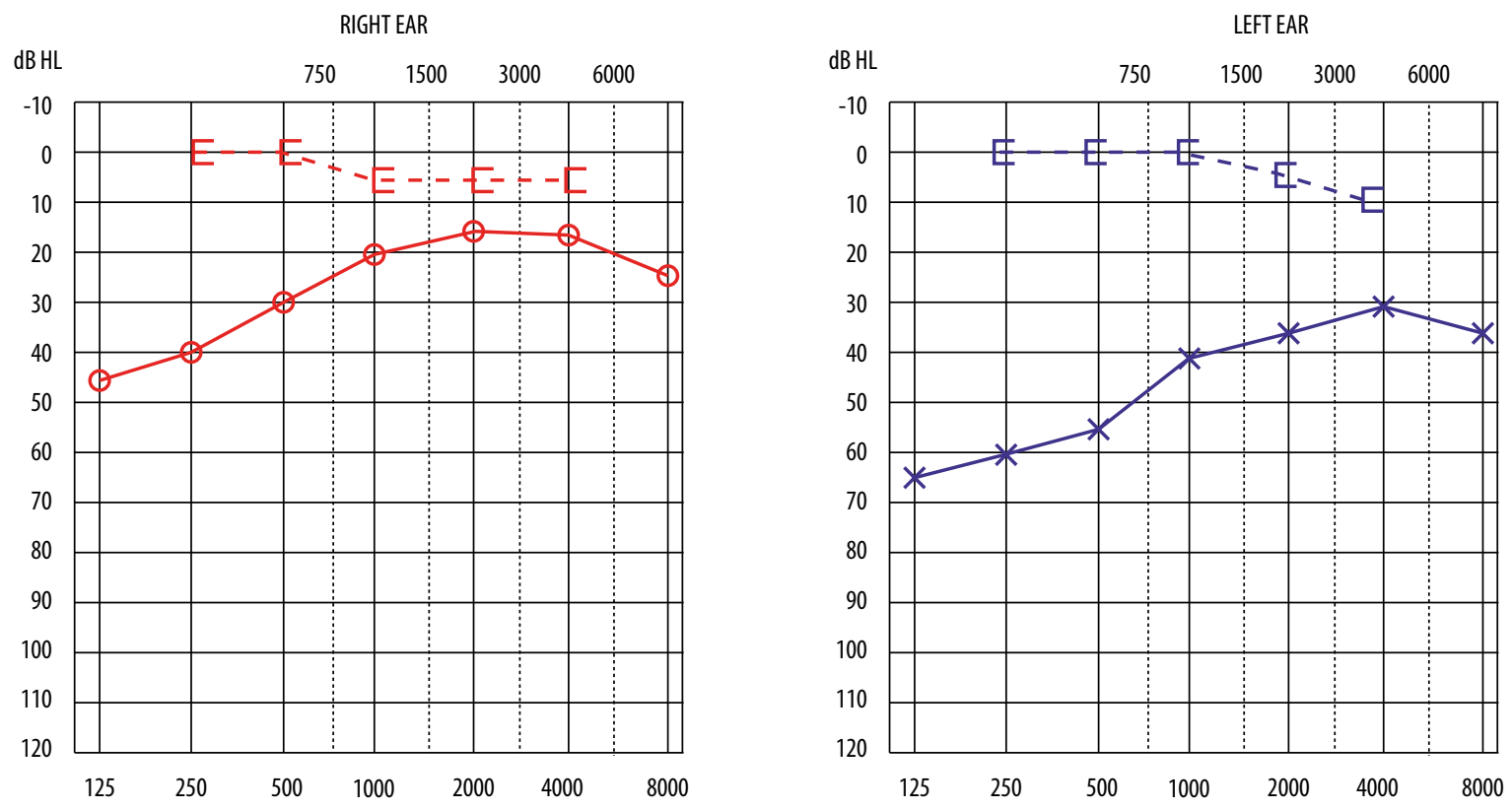

Figure 2. Preoperative results of pure-tone audiometry performed when the patient was 5 years old, showing reliable air and bone conduction thresholds in the right and left ear 
years and 2 months old, he had his first pure tone audiometry test. In the right ear the approximate air conduction threshold was at the level of 10-40 dB HL and in the left ear 25-60 dB HL (Figure 1). The child still did not tolerate hearing aids. He was tested with pure-tone audiometry again at 5 years of age, obtaining reliable air- and bone-conduction thresholds showing a conductive hearing loss in both ears (Figure 2). Impedance audiometry performed at the end of when the child was two and later when he was 5 did not detect the presence of acoustic reflexes from the stapedius muscles.

Moreover, in the left ear the child reported chronic tinnitus, and in the right ear intermittent tinnitus. For this reason, when he was 5 years and 1 month old, it was decided to perform exploratory tympanotomy in the left ear to evaluate the condition of the middle ear (to explore whether reconstruction surgery or stapedotomy was necessary). Before the surgery, a CT scan was performed in order to exclude middle and inner ear pathologies. CT images showed otosclerotic foci in the oval window area.

The tympanic cavity was reached using the typical approach to the middle ear through the external auditory canal. The view into the lumen of the tympanic cavity was slightly widened. After good visualization of the oval window area it was seen that the stapes was clearly immobilized and that there were concretions on the stapes footplate, as evidenced by a shallow oval window niche. The stapes superstrucure was removed in the typical way. Then an opening of $0.6 \mathrm{~mm}$ diameter was made in the thickened footplate using a diamond burr. Next, on the long process of the incus, a Kurz Skarzynski prosthesis of diameter $0.5 \mathrm{~mm}$ and length $4.5 \mathrm{~mm}$ was placed and clipped (the Kurz Skarzynski prosthesis varies from other available prostheses in terms of piston length). The piston was then sealed with a blood clot. No complications were observed in the postoperative period.

In follow-up examinations performed 1, 6, and 12 months after surgery, a significant improvement in hearing in the operated (left) ear was confirmed. The boy reported that he was not bothered by tinnitus in the operated ear, but he still complained about periodic tinnitus in the other. The latest pure-tone audiometry confirmed the long-term (after 1 year) subjective hearing benefits reported by both the child and his parents (Figure 3).

\section{Discussion}

Cases of otosclerosis diagnosed in children are very rare, which may be the reason for a certain reluctance to perform stapedotomy in children. It is still a controversial intervention in children (9), although it should be noted that this is an appropriate procedure giving good and stable results $(10,12,19-24)$. Albert et al. (25) noted in their study, similarly to other authors $(9,12,13,19-21)$, that stapedotomy performed in cases of juvenile otosclerosis gives better postoperative results than in cases of congenital stapes fixation or other causes of ossicular chain immobilization.

The appropriate age at which stapedotomy should be performed in children has not yet been established. To the authors' best knowledge, currently there are no reports of children younger than 5 years undergoing the procedure. Although the hearing results of stapes surgery in children may deteriorate over time, Yun and Kwan-Sun found that children who underwent stapes surgeries did not show an increased ABG over time (26). However, because childhood otosclerosis is rare and children commonly choose to use hearing aids in lieu of undergoing surgery, only a handful of results are currently available (27).
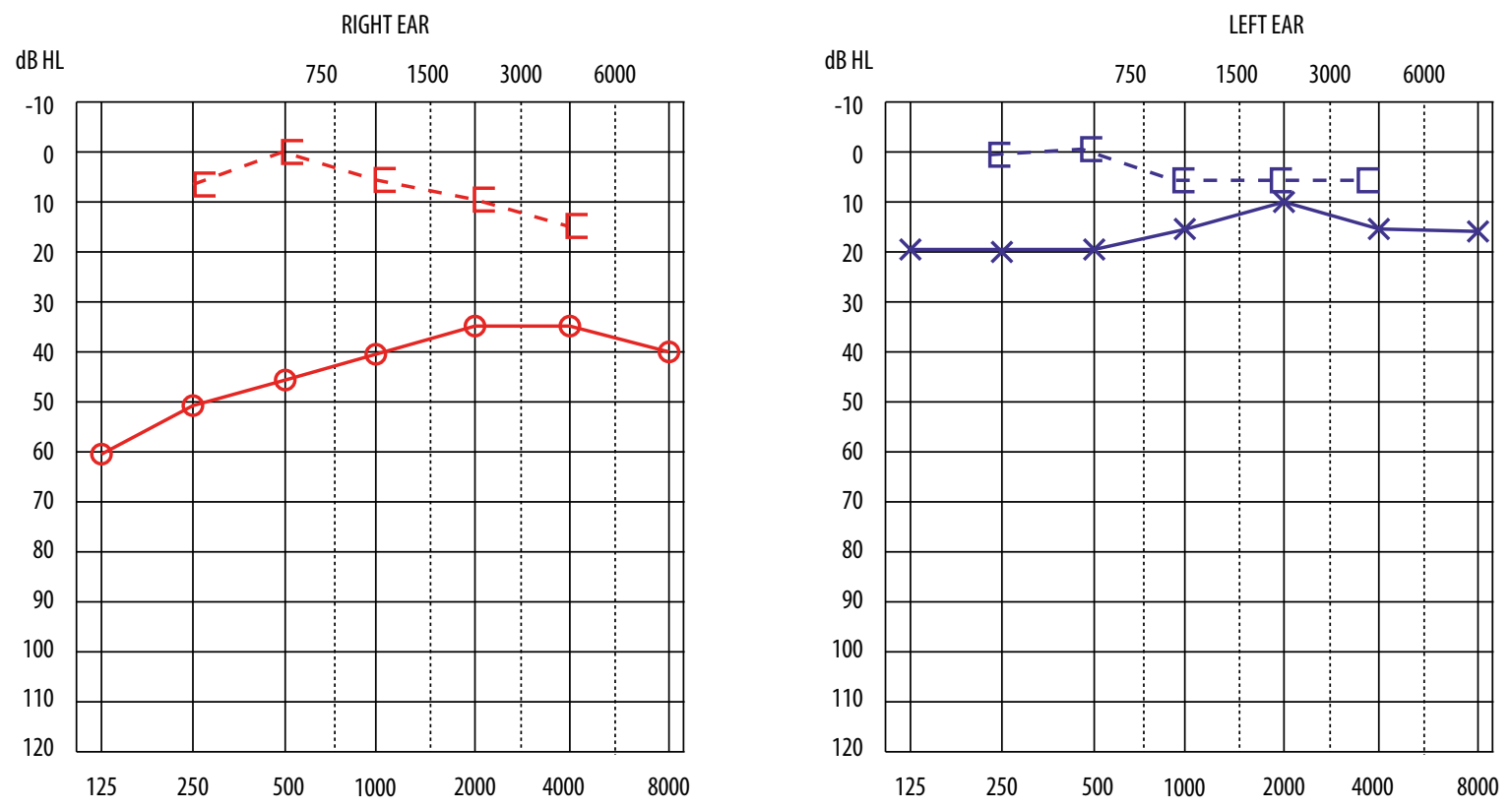

Figure 3. Results of pure-tone audiometry performed 12 months after operation, showing air and bone conduction thresholds for the right (not operated) and left (operated) ear 
The main concern about performing pediatric stapedectomy has been the risk of a stapes gusher and ensuing SNHL. Therefore, the option of a hearing aid to improve hearing should be discussed with the family - it is a costly, longterm, but risk-free alternative. Some authors recommend waiting for the child to reach an age where he or she can make an informed decision before a stapedectomy is performed, especially in unilateral cases (1).

The Baha Softband bone-conduction aid offers a third costly, long-term and complication-free treatment option for otosclerosis in patients who cannot or will not undergo stapedectomy and who have difficulty with conventional hearing aids (34). Young children or non-surgical candidates can still benefit from Baha by using the Softband (28).

Nevertheless, it should be remembered that only stapedotomy provides the opportunity to slow down, or even stop, the progression of the disease, and the above solutions do not do that. The results in our own studies, with measurements performed 1 month postoperatively and confirmed at follow-up 6 and 12 months later, shows very good results, with decreased thresholds for air conduction and bone conduction at two frequencies in the operated ear. It should also be noted that some thresholds deviate by only about $5 \mathrm{~dB}$, which in small children is absolutely normal and acceptable.

The child's subjective hearing levels might be affected by the changing level of perceived tinnitus in the operated ear and by the process of hearing in that ear. The stable results of hearing levels measured is comparable to the results obtained for older children and adolescents described in the literature $(11-13,16)$. Of note, deterioration of hearing in the other, not operated, ear was observed. An increase of air conduction threshold over a relatively short time attests to a very dynamic pathological process and this is an indication for surgical treatment in the right ear also, which should ensure that the child maintains normal levels of communication.
The results obtained by the described child, and operated on due to increasing bilateral hearing loss, confirm that age is not a contraindication for surgical treatment (16). This is important in the context that the child, who had significantly increased hearing thresholds at low frequencies and relatively lower ones at high frequencies, did not tolerate amplification with a classic hearing aid.

Based on our own experience and a literature review, we can state that indications for surgical intervention in children include:

- significantly decreased hearing sensitivity;

- presence of an air-bone gap;

- presence and increase of tinnitus;

- increased bone conduction thresholds.

It is recommended that, before any surgical intervention, a CT scan of the temporal bones should be performed in order to rule out congenital malformations of the middle and inner ear and posttraumatic ossicular damage. To provide the best outcomes, surgery should be performed by highly experienced otosurgeons in specialized hospitals.

\section{Conclusions}

Treatment of otosclerosis is indicated irrespective of a patient's age. Justification for deciding upon surgery for this 5 -year-old boy, probably the youngest described in the literature, was the diagnosis of significant progressive hearing loss and tinnitus, as well as growing bone conduction thresholds.

\section{Funding}

This research did not receive any specific grant from funding agencies in the public, commercial, or not-for-profit sectors.

Conflict of interest: The authors have no financial disclosure or conflicts of interest.

\section{References:}

1. Neilan RE, Zhang RW, Roland PS, Isaacson B, Lee KH, Walter Kutz J. Pediatric stapedectomy: does cause of fixation affect outcomes? Int J Pediatr Otorhinolaryngol, 2013; 77: 1099-102.

2. Guild SR. Histologic otosclerosis. Ann Otol Rhinol Laryngol, 1944; 53: 246-66.

3. Raveh E, Hu W, Papsin BC, Forte V. Congenital conductive hearing loss. J Laryngol Otol, 2002; 116: 92-6.

4. Syms CA, De la Cruz A. Pediatric otology. Otolaryngol Clin North Am, 1996; 29: 407-20.

5. Tringali S, Pouget J-F, Bertholon P, Dubreuil C, Martin C. Value of temporal bone density measurements in otosclerosis patients with normal-appearing computed tomographic scan. Ann Otol Rhinol Laryngol, 2007; 116: 195-8.

6. Lescanne E, Bakhos D, Metais JP, Robier A, Moriniere S. Otosclerosis in children and adolescents: a clinical and CT-scan survey with review of the literature. Int J Pediatr Otorhinolaryngol, 2008; 72: 147-52.

7. Fisher NA, Curtin HD. Radiology of congenital hearing loss. Otolaryngol Clin North Am, 1994; 27: 511-31.
8. Höhmann D, Dornhoffer J. Stapedectomy in congenital stapes fixation. HNO, 1995; 43: 65-9.

9. Asik B, Binar M, Serdar M, Satar B. A meta-analysis of surgical success rates in congenital stapes fixation and juvenile otosclerosis. Laryngoscope, 2016; 126: 191-8.

10. Millman B, Giddings NA, Cole JM. Long-term follow-up of stapedectomy in children and adolescents. Otolaryngol Head Neck Surg, 1996; 115: 78-81.

11. Lippy WH, Berenholz LP, Burkey JM. Otosclerosis in the 1960s, 1970s, 1980s, and 1990s. Laryngoscope, 1999; 109: 1307-9.

12. De la Cruz A, Angeli S, Slattery WH. Stapedectomy in children. Otolaryngol Head Neck Surg, 1999; 120: 487-92.

13. Denoyelle F, Daval M, Leboulanger N, et al. Stapedectomy in children: causes and surgical results in 35 cases. Arch Otolaryngol Head Neck Surg, 2010; 136: 1005-8.

14. Carlson ML, Driscoll CLW, Gifford RH, et al. Implications of minimizing trauma during conventional cochlear implantation. Otol Neurotol, 2011; 32: 962-8. 
15. Vincent R, Wegner I, Vonck BMD, Bittermann AJ, Kamalski DMA, Grolman W. Primary stapedotomy in children with otosclerosis: a prospective study of 41 consecutive cases. Laryngoscope, 2016; 126: 442-6.

16. Skarżyński PH, Dziendziel B, Boruta M, Skarżyński H. 278 stapedotomy procedures in children and adolescents. J Hear Sci, 2018 (in press)

17. Skarżyński H, Mueller-Malesińska M, Kochanek K, Senderski A, Ratyńska A. The models of uniform uniform newborn hearing screening program. Audiofonologia, 1997; 11: 173-81.

18. Skarżyński H, Mueller-Malesińska M, Kochanek K, Geremek A, Senderski A, Ratyńska A. Methods applied in neonatal hearing screening. Audiofonologia, 1997; 11: 147-58.

19. Robinson M. Juvenile otosclerosis. A 20-year study. Ann Otol Rhinol Laryngol, 1983; 92: 561-5.

20. House J, Sheehy J, Antunez J. Stapedectomy in children. Laryngoscope, 1980; 90: 1804-9.

21. Bachor E, Just T, Wright CG, Pau HW, Karmody CS. Fixation of the stapes footplate in children: a clinical and temporal bone histopathologic study. Otol Neurotol, 2005; 26: 866-73.
22. Cole J. Surgery for otosclerosis in children. Laryngoscope, 1982; 92: 859-62.

23. An YS, Lee K-S. The surgical results of stapes fixation in children. Int J Pediatr Otorhinolaryngol, 2014; 78: 55-9.

24. Vincent R, Sperling NM, Oates L, Jindal M. Surgical findings and long-term hearing results in 3,050 stapedotomies for primary otosclerosis: a prospective study with the otology-neurotology database. Otol Neurotol, 2006; 27: S25-47.

25. Albert S, Roger G, Rouillon I, et al. Congenital staples ankylosis: study of 28 cases and surgical results. Laryngoscope, 2006; 116: 1153-7.

26. Yun S, Kwang-Sun L. The surgical results of stapes fixation in children. Int J Pediatr Otorhinolaryngol, 2014; 78: 55-59.

27. Lippy WH, Burkey JM, Schuring AG, Rizer FM. Short- and long-term results of stapedectomy in children. Laryngoscope, 1998 Apr; 108: 569-72.

28. Hol MKS, Cremers CWRJ, Coppens-Schellekens W, Snik AFM. The BAHA Softband. A new treatment for young children with bilateral congenital aural atresia. Int J Pediatr Otorhinolaryngol, 2005; 69: 973-80. 